\title{
Farmakologik og lægemiddelomsorg
}

\section{Et etnografisk studie af mødet mellem sårbare xldre, hjemmepleje og medicin}

\section{Sofie Rosenlund Lau}

Afdeling for Almen Medicin, Københavns Universitet sola@sund.ku.dk

Lau, Sofie Rosenlund. 2021. Farmakologi og lægemiddelomsorg: Et etnografisk studie af mødet mellem sårbare ældre, hjemmepleje og medicin. Tidsskrift for Forskning i Sygdom og Samfund, nr. 35, 73-94

Mange ældre $i$ hjemmeplejen fär rigtig meget medicin heriblandt antidepressiv medicin. Med udgangspunkt i en praksis-teoretisk forskningsmetodologi undersøges sammenhængen mellem lægemidler og omsorg $i$ mødet med hjemmeplejen og sårbare ældre. I artiklen interesserer jeg mig således for en speciel form for omsorgsarbejde, lægemiddelarbejdet, udforsket gennem et etnografisk feltarbejde i en kommunal hjemmepleje. Inspireret af Mol (2008), opstiller jeg to modsatrettede logikker: Farmakologiens logik (eller farmakologik) og lægemiddelomsorgens logik. Jeg argumenterer for, at udbredelsen af medicin har rettet lagemiddelarbejdet mod farmakologiens generaliserende normer for god lagemiddelhåndtering og at dette er med til at forme den omsorg, der ydes for de xldre. Gennem tre empiriske eksempler viser jeg, hvordan farmakologikken flytter fokus væk fra medicinens sociale effekter, hoordan farmakologikken gør arbejdet med polyfarmaci til et instrumentelt og reduktionistisk pille-pilleri, og hvordan farmakologikken fremmer et fokus på god compliance, der skaber akavethed i mødet med den ældre, der udviser modstand mod medicin. Jeg afslutter artiklen med at foreslå et hypotetisk alternativ - lægemiddelomsorgens logik - og argumenterer for gevinsten ved at lade lægemiddelarbejdet styre af en mere dynamisk og fleksibel tilgang til medicin. 


\section{Pharmacologic and pharmaceutical care: An ethnographic study of the encounters between vulnerable elders, home care and medicines}

Many elderly people receive a great deal of medication including antidepressants. Based on a practice-theoretical research methodology, I explore the relations between medicines and care in encounters with home care personal and vulnerable seniors. In the article, I am thus interested in a particular kind of care practices, namely pharmaceutical care work, explored through an ethnographic fieldwork in a public home care. Inspired by Annemarie Mol (2008), I set up two opposing logics: The logic of pharmacology (or pharmacologic) and the logic of pharmaceutical care. I argue that the proliferation of medicines has directed pharmaceutical care work towards the pharmacologically induced, generalizing norms for good medication management and that these norms are shaping the care provided for the elderly. Through three empirical examples, I show how the pharmacologic shifts focus away from the social effects of medicines, how the pharmacologic makes the work of polypharmacy into an instrumental and reductionist pill-management and how the pharmacologic promotes a focus on good compliance that creates awkwardness in the encounters with seniors who show resistance towards medicines. I conclude the article by proposing a hypothetical alternative - the logic of pharmaceutical care - and argue for the benefits of letting pharmaceutical care work be guided by a more dynamic and flexible approach to medicines.

\section{Introduktion}

Medicin er en stor del af hverdagen hos mange danskere og i særdeleshed blandt ældre. Blandt de 80+ årige i Danmark får mere end hver tredje over 10 forskellige præparater om dagen (Christensen et al., 2019) og forbruget af receptpligtig medicin er steget væsentligt siden midten af 90'erne (Pedersen et al., 2020). Et eksempel på en konkret stigning i anvendelse af medicin findes blandt de antidepressive midler - SSRI'erne (Selective Serotonin Reuptake Inhibitors). I 2019 indløste lige knap 150.000 danskere over 65 år en recept på antidepressiva, hvilket svarer til $13 \%$ af den samlede befolkning over 65 (Sundhedsdatastyrelsen, 2020) ${ }^{1}$. Forbruget af antidepressive midler er særligt højt blandt de allerældste. I et nyt registerstudie af udviklingen i lægemiddelforbrug på danske plejehjem ses, at $51 \%$ modtager antidepressiv behandling 6 måneder efter indflytning på plejehjem, og forbruget stiger, således at der 3 år efter indflytning er 66\%, der får antidepressiv medicin (Lundby et al., 2020). Lægemidlerne synes altså at spille en særlig rolle i ældreple- 
jen i relation til ældres mentale sundhed (Midlöv et al., 2014; Wiese, 2011). Samtidig har udbredelsen af antidepressiva skabt grobund for voldsom debat, der ofte tager udgangspunkt i kontroverser omkring medicinens (farmakologiske) effekter og sikkerhed. På den ene side argumenteres for, at depression i en sen alder er underdiagnosticeret og underbehandlet, og at medicinen hermed er berettiget, ja måske ligefrem underanvendt (Wiese, 2011; Wilkinson et al., 2018). På den anden side påpeges, at medicinens effekt på behandling af depression er tvivlsom særlig blandt de ældre, hvor risikoen for negative følgevirkninger ( $f x$ svimmelhed, fald og indlæggelser) samtidig er større (Hickie, 2011; Lundby et al., 2020; Rosholm et al., 2002). I den kritiske samfundsvidenskabelige litteratur anses udbredelsen af antidepressiv medicin ofte som et eksempel på (bio)medikalisering, hvor (sociale) tilstande som depression i stigende grad forstås som afgrænsede sygdomsentiteter, hvis årsag skal findes og behandles i individers biologi (Clarke et al., 2003; Rosenberg, 2006). Antidepressiva i den forstand passer ind i biomedicinens "magic bullet model", hvor sygdomme reduceres til målbare fejl (fx et for lavt niveau af transmitterstoffer i hjernen), og hvor løsningen skal findes i specifikke kemiske og biologiske stoffer, der kan udbedre denne fejl (fx ved at hæmme genoptagelsen af transmitterstoffer og dermed øge koncentrationen af stofferne i hjernecellesynapserne). Begrebet farmaceutikalisering rækker dog udover forandringer i forståelsen af sociale tilstande som medicinske entiteter til også at inkludere forandringer i markedskræfter, særligt lægemiddelindustriens massive vækst, i styringen af disse kræfter fra et neoliberalt perspektiv og i forbrugeradfærd og distribuering af viden fra professioner til lægmand (Abraham, 2010; Gabe et al., 2015). Farmaceutikaliseringslitteraturen beskæftiger sig altså i høj grad med globale, historiske forandringer i forståelser af sygdom og tager ofte udgangspunkt i Foucauldianske analyser af magt og (selv)styring (Bell and Figert, 2012).

I denne artikel anvender jeg et helt tredje syn på forbruget af antidepressiva med udgangspunkt i en praksis-teoretisk forskningsmetodologi (Mol, 2002; Mol et al., 2010; Will, 2017). Jeg interesserer mig nemlig for, hvad medicinen gør i specifikke møder mellem ældre, deres pårørende og sundhedsprofessionelle. Med denne tilgang forsøger jeg at tage afstand fra de meget kritiske, reduktionistiske studier, der ofte tilgår lægemidler som generelt problematiske og ildesete, og ønsker i stedet at fokusere på, hvordan specifikke konstellationer, hvor lægemidler indgår som aktør, både fremmer og hæmmer omsorgsarbejde. Teoretisk anses antidepressiv medicin i denne artikel som en omsorgsteknologi-en materiel "ting", der yder pleje i relation til personer, der har behov for særlig omsorg (Hasse and Wallace, 2014: 84). Samtidig tænkes lægemidlerne ikke som passive værdineutrale 
objekter men derimod som entiteter, der, i samspil med mennesker, har sociale liv og rummer kapacitet til at skabe forandring i forståelser og oplevelser af sundhed og sygdom, kroppe og subjektivitet (Collin, 2016; Hardon and Sanabria, 2017; Whyte et al., 2002). Med andre ord - medicinens tilstedeværelse gør noget ved måden, vi opfatter os selv og hinanden på, ved vores handlemønstre og ved vores relationer. Hasse og Wallace bruger begrebet kulturøkologi til at pege på den evigt foranderlige helhed af relationer (mellem mennesker og mellem mennesker og teknologier), som omsorgsteknologier nødvendigvis er en del af for at virke. For at forstå teknologiernes betydning i praksis er det derfor ikke nok at forstå teknologien, man må også forstå de komplekse relationelle konstellationer, som teknologierne indgår i (Hasse and Wallace, 2014).

Ved at anlægge dette relationelle blik på antidepressiva i ældreplejen flyttes fokus fra de (i biomedicinens forstand) rationelle årsager til over/underforbrug, og søger i stedet mod at forstå hvilke betydninger udbredelsen af antidepressiva har, for det omsorgsarbejde hjemmeplejen yder i mødet med den ældre borger. Omsorgsarbejdet (på engelsk care practices) skal her forstås som det praktiske arbejde, der ligger i at drage omsorg for et andet menneske i en konkret situation og behandles i artiklen både som empirisk og analytisk objekt (Mol et al., 2010)². I artiklen interesserer jeg mig således for en speciel form for omsorgsarbejde, lægemiddelarbejdet, udforsket gennem et etnografisk feltarbejde i en kommunal hjemmepleje i en forstad til København. Inspireret af Mol (2008) opstiller jeg i artiklen to modsatrettede logikker: Farmakologiens logik og lægemiddelomsorgens logik. Jeg argumenterer for, at udbredelsen af medicin har rettet lægemiddelarbejdet mod farmakologiens generaliserende normer for god lægemiddelhåndtering, og at dette er med til at forme den omsorg, der ydes for de ældre. Gennem feltarbejdet observerede jeg, hvordan lægemidlerne gentagne gange påvirkede relationerne mellem sårbare ældre og hjemmeplejen. I det følgende beskriver jeg disse påvirkninger gennem tre empiriske eksempler, der omhandler; sociale effekter, pillepilleri, og akavede møder.

\section{Farmakologiens logik versus lægemiddelomsorgens logik}

I denne artikel anvendes termen farmakologiens logik - eller farmakologik - til at påpege, hvordan en særlig logik former de rationaler, der er på spil i hjemmeple- 
jens arbejde med medicin og hermed også omsorgsarbejdet. Farmakologikken er baseret på farmakologiens grundprincipper for korrekt og sikker medicinhåndtering og er i den forstand den biomedicinske, rationelle tilgang til god lægemiddelpraksis styret af en særlig forestilling om, hvordan lægemidler anvendes bedst muligt i hænderne på sundhedsprofessionelle og patienter. I Danmark er det Styrelsen for Patientsikkerhed, der som den overordnede sundhedsfaglige tilsynsmyndighed udstikker retningslinjerne for medicinhåndtering i ældreplejen. Et øget fokus på sikker medicinering er opstået i kølvandet på en lang række sager om rod i medicinen på plejehjem og botilbud, der har fået både kommunerne og Styrelsen for Patientsikkerhed til at skærpe deres tilsyn med medicinarbejdet. Enkelte sager hvor fejl i medicinhåndteringen har ført til dødsfald, heriblandt en sag hvor en ældre på plejehjem i en periode på 10 dage fik gigtmedicin dagligt i stedet for en gang om ugen, har været i pressens søgelys og dermed også været med til at rette en bredere opmærksomhed på problemer med medicinhåndtering i ældreplejen. Det antages desuden, at omkring hvert tiende indlæggelse i Danmark skyldes et lægemiddelrelateret problem (Søndergaard et al., 2006).

Kort fortalt foreskriver retningslinjerne for korrekt og sikker medicinhåndtering, hvordan medarbejderen i sundheds- og socialsektoren på systematisk vis, skal sikre at det rigtige medicin gives til den rigtige borger, i den rette dosis, på den rigtige måde, på det rette tidspunkt, i den rette form (Styrelsen for Patientsikkerhed, 2019). Denne politiske værdisætning for god lægemiddelbehandling bliver i praksis styrende for hjemmeplejens arbejde med medicin (se også Lau, 2020). Med andre ord udgør dette særlige blik på medicin (som beskrives nærmere i det følgende) en særlig løsningsmodel (Jöhncke et al., 2004) for problemer der opstår i mødet mellem hjemmeplejen og den ældre borger. Løsningsmodellen baseres på en særlig rationalitet i forhold til, hvad god medicineringspraksis er både hvornår medicin med rette kan anvendes, og hvordan den bør håndteres i de ældres liv. Farmakologikken er herved med til at præge den relationelle omsorg, da den bliver styrende for møder mellem borgere og hjemmepleje, der omhandler medicin.

Med denne artikel ønsker jeg at foreslå et alternativ til farmakologik i mødet mellem borgere og hjemmepleje - en mere dynamisk logi styret af lokale, situationelle forstålser af omsorg, der tilstræber at gøre medicinanvendelsen meningsfuld i det specifikke møde med den enkelte ældre borger. Inspireret af Annemarie Mols kendte værk, The Logic of Care - Health and the Problem of Patient Choice (2008), foreslår jeg lægemiddelomsorgens logik som dette alternativ. I Mols arbejde sammenlignes to måder at anskue og praktisere forholdet mellem patient og 
sundhedsvæsen; henholdsvis valgfrihedens logik (logic of choice) og omsorgens logik (logic of care). Valgfrihedens logik repræsenterer idealet om det individuelle frie valg og tendensen til at lade dette ideal være styrende for mødet med patienten i mange sammenhænge på tværs af sundhedssektoren med nøgleord som brugerinddragelse, fælles beslutningstagen og egenomsorg. Mol kritiserer denne tilgang for at lægge unødigt ansvar på (ofte skrøbelige) patienter på baggrund af en indlejret stræben efter det "normale" (sunde) liv. Gennem empiriske eksempler fra diabetesbehandling viser hun, hvordan valgfrihedens logik er baseret på en forestilling om sygdom og behandling som lineære forløb og valg som afgrænsede i tid og rum. Alternativet, omsorgens logik, repræsenterer en pragmatisk tilgang til livet med sygdom med alle de uventede oplevelser og erfaringer, der følger med. I omsorgens logik er målet ikke at træffe valg men at eksperimentere, erfare og handle i hverdagen for at imødekomme de mange uforudsigeligheder, som ofte følger med livet med kronisk sygdom. I forlængelse af Mol foreslår jeg lægemiddelomsorgens logik, hvor lægemiddelhåndtering ikke betinges af farmakologiske rationaler for god og dårlig praksis men derimod af, hvad der giver mening for den enkelte her og nu. I lxgemiddelomsorgens logik er målet ikke udelukkende at få den rigtige medicin givet og indtaget korrekt, men derimod at sikre at den ældre oplever, at medicinen skaber mening, og at mødet mellem hjemmepleje og den ældre antager en form, hvor denne mening (eller mangel på samme) kan undersøges, erfares og formidles. Fokus er således ikke på medicinen per se men på relationerne mellem lægemidlerne, hjemmeplejen og de ældre, og på hvordan disse relationer løbende ændrer sig, i takt med at konteksten omkring den enkelte borger og hjemmeplejen ændrer sig.

\section{Metodiske aspekter}

\section{Det etnografiske feltarbejde}

Artiklen er en del af en postdoc forankret ved Center for Forskning og Uddannelse i Almen Praksis ved Københavns Universitet og er finansieret af Velux Fondens pulje om ældre og medicin. Empirien til artiklen kommer fra et feltarbejde i en kommunal hjemmepleje spredt over perioden april 2019 til februar 2020. Feltarbejdet udgik fra hjemmeplejens kontorer, hvor jeg mødte ind med de ansatte om morgenen og var med til morgenmødet i en af de fire områdegrupper. Møderne gav 
anledning til at høre, hvad der rørte sig i personalegruppen og blandt borgerne ${ }^{3}$. Det var ofte ved disse møder, at det blev nævnt, hvis der var opstået særlige situationer i hjemmene, som kollegaerne havde brug for at spare med hinanden. Det var desuden her, at overlevering mellem hjemmepleje og hjemmesygepleje fandt sted. Hjemmeplejen, der består af social- og sundhedshjælpere samt ufaglærte, tager sig primært af personlig pleje, såsom hjælp til vask eller bad, af- og påklædning og toiletbesøg, samt af praktiske opgaver i hjemmet såsom rengøring, madbestilling og tøjvask. Hjemmeplejen udleverer også medicin til borgerne, hvilket indbefatter at medicinen flyttes fra præpakkede dosisposer eller doseringsæsker til f.eks. et medicinbæger eller kop, hvorfra borgeren selv kan indtage eller få hjælp til at indtage medicinen. Indkøb, levering, opbevaring og dispensering af medicinen varetages derimod af hjemmesygeplejen, der inkluderer både sygeplejersker og social- og sundhedsassistenter. Det er også hjemmesygeplejen, der har den primære kontakt til de praktiserende læger, selvom alle i hjemmeplejen kan kommunikere med lægerne gennem det elektroniske omsorgssystem. Mit feltarbejde har primært centreret sig omkring hjemmesygeplejen, men jeg har gennem ophold i borgernes hjem også observeret hjemmeplejernes arbejde. Gennem samtaler med personale i både hjemme- og hjemmesygepleje rekrutterede jeg i starten af projektet 11 borgere, som alle var over 60 år, var tildelt hjemmehjælp, fik hjælp til medicinhåndtering og tog antidepressive midler uden dog at have svære psykiatriske lidelser eller udtalt kognitiv svækkelse. Jeg har gennem feltarbejdet løbende besøgt og interviewet de 11 ældre i deres hjem og hos fire af borgerne også pårørende (partnere eller voksne børn). Alle 11 borgere samtykkede til deltagelse ved første møde, dog måtte en efterfølgende melde fra, da han synes, han var for dårlig. Empirien består desuden af interviews med 7 praktiserende læger, hvoraf 4 har en eller flere af de deltagende ældre som patient i deres praksis. Mundtligt samtykke til min deltagelse i hjemmeplejens arbejde var en forudsætning for samtlige besøg i hjemmene. Ved interviewene blev indhentet både mundtligt og skriftligt samtykke og projektet er godkendt af Datatilsynet og hos Videnskabsetisk Komité (journalnr. H-19024756).

\section{Sårbarhed i mødet med svækkede xldre}

I Danmark er kommunerne inddelt i fire socialgrupper beregnet på baggrund af andelen af borgere uden for arbejdsmarkedet, andelen af borgere med kort uddannelse samt den gennemsnitlige bruttoindkomst i kommunen. Kommunen, hvor dette projekt har fundet sted, ligger i socialgruppe 4, hvilket også afspejles i em- 
pirien. Udsathed, eller nærmere sårbarhed blev således hurtigt en tilstedeværende faktor blandt deltagerne til trods for, at det ikke var en del af rekrutteringsstrategien. Sårbarhedstermen anvendes her, fordi den rummer mere end begreberne udsathed eller ulighed i beskrivelsen af de ældres liv og livsomstændigheder. Grøn og Andersen (2014) har i forsøget på at indfange, hvad sårbarhed i alderdommen er, inddelt begrebet i seks dimensioner relateret til: kropsligt forfald, udsathed, ulighed, skrøbelighed, netværk og familie, og pleje og kompensation. For samtlige deltagere i projektet var flere af dimensionerne til stede. Dette gjaldt i særdeleshed tilstedeværelsen af flere kroniske sygdomme (multimorbiditet), misbrug eller højt forbrug af alkohol eller medicin nu eller tidligere i livet, materiel eller økonomisk ulighed (flere af deltagerne boede f.eks. i kommunale boligbyggerier af ringe stand), begrænset socialt- og familiært netværk og behov for daglig hjælp til personlig pleje og praktiske opgaver i hjemmet (hvor sidstnævnte dog var led i rekrutteringsstrategien). Sårbarhed har ikke været behandlet som specifikt tema i feltarbejdet, og derfor har jeg heller ikke spurgt deltagerne direkte, om de følte sig sårbare (hvilket Grøn og Andersen (2014) referer til under dimensionen skrøbelighed). Jeg har til gengæld spurgt alle, hvordan de har det, og det har i de fleste situationer åbnet op for indsigter i hverdagsliv, der er præget af svækkede kroppe, ensomhed, utilstrækkelighed i forhold til hvad man tidligere har kunnet, og til tider også afmagt og livslede. Det er således en særlig gruppe af ældre, som dette studie er endt med at fokusere på, og det er sandsynligt, at medicinen ville spille en anden (potentielt mindre udtalt) rolle i mødet med ældre i mindre sårbare situationer.

\section{Etiske overvejelser}

Der er flere etiske udfordringer forbundet med at lave feltarbejde blandt ældre i sårbare situationer, hvoraf flere har hukommelsesbesvær eller begyndende demens. I feltarbejdet undgik jeg i vid udstrækning personer med udtalt kognitiv svækkelse eller demensdiagnoser. Olav, som jeg indleder næste afsnit med, er her en undtagelse, da det var Olavs hustru Inge, der var den primære kontakt. Selvom der er indhentet mundligt og (om muligt) skriftligt samtykke fra alle borgere, er det ikke sikkert, at det informerede samtykke reelt er opnået, da de ældre kan glemme eller sammenblande informationer omkring min tilstedeværelse (se også Felding and Schwennesen, 2019). For eksempel oplevede jeg flere gange, at den ældre troede, at jeg var sygeplejerske og var på besøg i regi af hjemmeplejen. For at imødekomme dette gjorde jeg flere gange under min tid i hjemmene opmærksom på, hvorfor jeg var der. Dog var det ikke altid muligt fuldt at forklare hensigten 
med projektet, da forskningsterminologien og indsigter i medicinering ikke altid var meningsfuldt for den ældre. Jeg forsikrede mig dog løbende, at deltagerne accepterede min tilstedeværelse. Alle var glade for mine besøg, for vores samtaler og for at kunne bidrage med indsigter fra deres liv og hverdag. Alle besøg sluttede af med forespørgsel om at vende retur, og alle forespørgsler blev imødekommet og værdsat. For at sikre anonymisering er samtlige deltagere i projektet tildelt pseudonymer.

\section{Sociale effekter}

Olav på 89 bor sammen med sin kone Inge i et etplans murstenshus for enden af en lukket vej. Olav har selv bygget huset tilbage i 73, og Inge viser stolt hjemmet og alle minderne frem. Olav har haft et aktivt erhvervsliv, der involverede et utal af firmamiddage, og Inge, der var hjemmegående, elskede at være vært for de danske og udenlandske gæster. Nu er hjemmet for det meste stille. Olav holder til i det bagerste værelse, hvor han sover på sofaen og opholder sig det meste af dagen. Om natten hænder det ofte, at han vandrer hvileløst rundt i det mørke hus. Olav lider af Alzheimers demens og får episoder af angst og delir. Det sker også, at han forlader hjemmet, ofte om natten, og han er flere gange blevet indlagt efter fald forbundet med disse nattevandringer. Han har været i rehabilitering og også en enkelt gang $\mathrm{i}$ aflastning på det lokale plejecenter, men opholdene har været præget af uro og angst. "Han troede, han var i fangsel. Han var så bange, så angst for at være der" fortæller Inge med sorg i stemmen. Olav er heller ikke glad for de mange mennesker, der kommer i hjemmet for at yde pleje, og han kan blive opfarende og vred. Det havde været under optrapning længe, men en dag gik det helt galt, da Olav truede hjemmeplejen med en økse, fordi han troede, at de var trængt ulovligt ind i hans hus. Familien og hjemmeplejen henvendte sig i samråd til Olavs praktiserende læge, der udskrev antidepressiva for at "få Olav til at falde ned". I et interview med den praktiserende læge taler vi om, hvordan det kommer så vidt, og lægen beskriver kompleksiteten omkring hjemmeplejen, der gerne vil gøre deres arbejde godt, men som har begrænsede ressourcer, og situationen i hjemmet, der kræver særlig forståelse og fleksibilitet: "De [hjemmeplejen og familien] bliver jo magtesløse. Fordi, jamen, hvad skal vi så gøre? Det [den antidepressive medicin] var sådan lidt deres sidste håb - for at passe patienten, ikke." Samtidig er lægen også klar over, at Olav kræver et særligt tag, som ikke alle måske er opmærksomme på eller har ressourcer til at håndtere. Som lægen siger: "Hans arbejde var alt for ham, så det er 
det, han vil tale om nu. [...] Hvis man bare giver ham tid til lige at fortælle om det, så er det fint nok, så falder han ned. Men hvis man stopper ham, så bliver han jo vred, fordi man stopper hans fortælling."

I farmakologiens logik er lægemidler til for at løse et mere eller mindre velkendt og defineret biologisk problem. Antidepressiva bliver udskrevet for at øge mængden af signalstoffer i hjernen (særligt serotonin og noradrenalin), og hermed modvirke den ubalance man, i den (her forsimplede) biomedicinske forståelse af tilstanden, mener er årsagen til depressive symptomer. Diskussionen af, hvorvidt denne årsagsforklaring er tilstrækkelig, er spændende, men rækker ud over denne artikels formål. Hvad eksemplet med Olav derimod viser, er, at effekterne af medicinen flyder langt ud over Olavs hjerne og krop. I praksis skaber medicinen muligheden for at holde Olav hjemme i en tilstand, hvor både Inge og hjemmeplejen kan være omkring og sikre, at Olav og hjemmet bliver passet. Medicinen stopper Olavs nattevandringer, så Inge er bedre i stand til at passe på ham og undgår de voldsomme episoder med indlæggelser, og medicinen dæmper Olavs angst og agitation, således at hjemmeplejen trygt kan komme i hjemmet og udføre opgaver for både Inge og Olav. Effekten er altså ikke begrænset til det, der står på indlægssedlen, og som var målbart i de kliniske studier inden lægemidlet blev markedsført. Tværtimod skal effekten her forstås som en kompleks interaktion mellem de mange aktører til stede i Olavs liv. Som Hardon og Sanabria (2017) skriver i deres review af antropologiske studier af lægemidler: "Indeed, pharmaceutical actions continue to be actualized, modified, and reactualized in care settings." (123) I mødet mellem hjemmet og hjemmeplejen er det altså ikke nok at forstå de antidepressive midlers effekt i Olavs krop - for effekterne rækker ud over det stabile, afgrænsede og målbare og kan med fordel tænkes som sociale (Whyte et al., 2002: 35). Sociale effekter påvirker sociale relationer, hvilket, som Whyte, van der Geest og Hardon påpeger, kan være med til at forklare, hvorfor nogle behandlinger efter noget tid bliver automatiserede eller "instinktive". Hvorimod lægemiddelforskningen er underlagt stramme krav til fokus på lægemidlers effekt, gælder andre normer, når lægemidlerne først er ude og virke i praksis. Der er f.eks. ikke specifikke krav til, at lægemiddelbrugeren skal indrapportere effekter af medicinen, ligesom hverken lægen eller hjemmeplejen nødvendigvis er opmærksomme på, om medicinen faktisk virker efter hensigten. Det er ofte kun, hvis medicinen absolut ingen effekt har ( $f x$ hvis smerterne eller feberen vedbliver), at man får øjnene op for alternativer. I praksis anvendes meget medicin uden bevidst ræsonnement, men hvor forbruget i stedet baseres på vaner: "People are acting in ways that make sense to them, because they make sense to others. That sense is about exerting control, sho- 
wing care, doing what is considered best" (Whyte et al., 2002: 36). Dette kan forklare, hvorfor så mange ældre får udskrevet antidepressiva, uden at den biomedicinske effekt er fuld dokumenteret. I tilfældet med Olav er medicinens evne til at holde sammen på hjemmet årsag nok til at legitimere dens brug.

Problemet opstår, når medicinen potentielt kan gøre skade. For eksempel er en almindelig bivirkning ved SSRI'er svimmelhed og kraftesløshed, hvilket for en mand som Olav potentielt kan øge risikoen for alvorlige fald. Den subtile legitimering af medicinens sociale effekter må derfor ses i lyset af de alternativer, der kunne være til medicin og som italesættes af lægen i interviewet. Olav oplever qua sin demens udtalt frustration, hvilket kommer til udtryk gennem vredesudbrud og til tider også direkte trusler. Han kan ligefrem blive voldelig, hvis han bliver utryg (som var tilfældet med øksen). Men denne tilstand kan beroliges, hvis man giver ham tid. Tid til at fortælle om de minder, der sidder fast i hukommelsen. Tid til at give ham en stemme og få ham til at føle sig anerkendt. Udfordringen opstår, fordi hjemmeplejen, af strukturelle årsager, ikke har den tid, der er nødvendig for at gøre Olav tryg. Når det hver dag er nye mennesker, der kommer i hjemmet, og når der kun er indregnet en halv time til at støvsuge og sørge for personlig pleje og morgenmad, så er der ikke tid til at sætte sig ned og lytte til Olavs gentagne fortælling om hans forretningsrejser i Asien, og til at forstå at denne fortælling er vigtig for Olavs oplevelse af at blive set og hørt i relationen til de fremmede, der kommer i hans hjem, og hvis hensigter han ikke altid forstår. Farmakologikken tager fokus væk fra alternativer til medicin og foreskriver i stedet lægemidlerne som en legitim løsning på problemer, der måske med fordel kunne være løst på anden vis.

\section{Pille-pilleri}

"Døren er åben", råber Carl fra stolen i stuen. Sygeplejersken går ud i køkkenet og forsøger at skabe sig overblik over medicinen. Der er meget. Medicinæskerne ligger i poser på gulvet og i bunker på det runde bord, der engang fungerede som spisebord, men som nu er udelukkende dedikeret til medicin. Carl kommer gangbesværet ud til os og finder en pose med apotekets logo - "Det er det nyeste" siger han og smider uden synderlig interesse posen på bordet. Sygeplejersken er hos Carl for at dosere hans medicin. Medicinen skal flyttes fra fabriksæskerne og over i såkaldte doseringsæsker, der indeholder et etui per dag. Hvert plastiketui er mærket med morgen, middag, aften, nat, hvilket gør det nemt for hjemmehjæl- 
perne og for Carl selv at sørge for, at han får de rigtige piller på det rigtige tidspunkt af dagen. Carl får 34 tabletter hver dag, flest om morgenen, og de mange forskellige behandlinger gør arbejdet med medicinen komplekst. Sygeplejersken havde allerede været i gang dagen før men måtte stoppe, da der manglede piller til de sidste dage. Nu har Carl fået hentet det sidste medicin på apoteket, så sygeplejersken kan færdiggøre doseringen. Hun sætter sig ved bordet og går i gang. Carl trisser, støttende til rollatoren, ind i stuen igen og sætter sig tilbage i stolen med et smertende suk. Sygeplejersken bruger over en time på at få medicinen på plads. Det er ved at være sent på eftermiddagen, og hun når kun lige at stikke hovedet ind i stuen og sige farvel, før hun suser ud af døren, videre til den næste. Carl vinker fraværende til hende fra sin stol.

Carl er 81. For ti år siden mistede han sin kone, og i den forbindelse også kontakten til sin ene søn. Carl genvandt dog glæden i hverdagen og synes selv, at han har haft nogle gode år som aktiv i den lokale ældreforening og i selskab med sin kæreste og nabo. Det er først de sidste par år, at det for alvor er begyndt at gå ned af bakke. Carl har været ramt af en lang kaskade af sygdom - hjertesygdom, kræft, nyresvigt og brok - og har været igennem et hav af hospitalsindlæggelser og operationer. Efter den sidste indlæggelse er en gammel rygskade blusset op, og det volder ham nu voldsomme smerter og bevægelsesbesvær. Medicinen er fulgt med de mange indlæggelser og diagnoser. Han er træt af at spise de mange piller men ser ikke nogen vej udenom. Den antidepressive behandling, der nu kun udgør en enkelt lille pille i bunken af medicin, er ikke længere noget, der fylder. Det gør den samlede medicinering til gengæld. De mange lægemidler skaber uro i Carls mavetarmsystem i så høj en grad, at han ikke længere tør bevæge sig væk fra hjemmet (smerterne gør dog i sig selv længere ture umulige). Han døjer skiftevis med sure opstød, kvalme, diarre og forstoppelse, og har svært ved at indtage anden føde end Faxe Kondi og nogle proteinyoghurt, som lægen har ordineret. Medicinen gør ham også døsig, og han bruger det meste af dagen i stolen foran fjernsynet. Det hænder, at han falder i søvn og først vågner næste morgen fuld påklædt i lænestolen med fjernsynet kørende.

Ældre med meget sygdom, mange kroniske lidelser og tilsvarende lange medicinlister er et velkendt fænomen i hjemmeplejen. Gennem feltarbejdet erfarede jeg således hurtigt, at medicin generelt fylder meget i de ældres liv i den forstand, at de fleste tager flere forskellige slags medicin flere gange dagligt. Polyfarmaci - altså samtidig anvendelse af meget medicin - gjorde det nærmest umuligt at opretholde et fokus på antidepressiva, når hjemmene, som hos Carl, vitterligt flød med medicin. Det gav simpelthen ikke mening kun at tale om én lille pille, når den daglige 
ration af lægemidler i alle tilfælde bestod af langt mere. Antidepressiva forsvandt således både i den praktiske håndtering af medicinen og i samtaler om medicinen, hvor hverken de ældre selv eller hjemmeplejen i særlig høj grad skelnede mellem de forskellige farmakologiske behandlinger, medmindre jeg spurgte dem direkte. Det der i stedet kom til at fylde, var den fysiske eller materielle håndtering af det meget medicin. Lægemiddelarbejdet blev i den henseende formet af mængden af medicin, der skulle tages vare om. Når hjemmeplejen håndterer medicin i borgerens hjem, handler de i juridisk forstand som den ordinerende læges medhjælp. Dette betyder også, at de er forpligtet til at udføre arbejdet efter arbejdsstedets instruks for lægemiddelhåndtering, og at de også kan hæfte personligt for ikke at udføre arbejdet korrekt. Lægemiddelarbejdet antager i denne konstellation også en juridisk form, hvor sygeplejersken, som lægens juridiske medhjælp, har ansvar for dokumentere, at medicinarbejdet udføres korrekt.

Jeg referer til dette lægemiddelarbejde som pille-pilleri, ikke for at negligere kompleksiteten eller vigtigheden af at sikre den ældre den rigtige medicin, men fordi dette arbejde er så stærkt fokuseret på lægemidlernes fysiske tilstedeværelse i samspil med dokumentationssystemerne og så lidt på det menneske, som medicinen er påtænkt. (Sygeplejerskerne i studiet refererede selv til medicinarbejdet som "at spille Kalaha" for at påpege det materielle og til tider monotome arbejde i at hælde medicin i doseringsæskerne (se Lau, 2020)). Pille-pilleriet er ofte så krævende, at det tager al sygeplejerskens opmærksomhed. Farmakologikken rammesætter således et særligt instrumentelt syn på medicinhåndtering, som i mødet med borgeren kommer til at virke mekanisk og reduktionistisk. Med de komplekse medicineringsregimer følger altså et komplekst lægemiddelarbejde, men hvor omsorgen primært er rettet mod medicinen. Til gengæld spiller inkluderingen af den ældre i lægemiddelarbejdet ingen væsentlig rolle. I retningslinjen for sikker medicinhåndtering står ligefrem anført, at dispenseringen skal foregå uforstyrret, og sygeplejerskerne er derfor i deres fulde ret til at bede borgeren være stille eller, som hos Carl, helt forsvinde væk fra arbejdsområdet. Carl har vænnet sig til det og virker ligeglad. Pille-pilleriet er ikke meningsfuldt for ham. Han er træt af sin medicin. Men han er også syg og svækket. Lægemiddelarbejdet foreskriver dog ingen særlig opmærksomhed på Carls egne oplevelser med medicin eller på, om der måske med fordel kunne justeres i hans medicinering for at give ham en bedre hverdag uden maveproblemer og træthed. 


\section{Akavede møder}

Betty på 79 ligger i sengen, da hjemmehjælperen og jeg kommer ind. Hun gaber højlydt og brokker sig over den tidlige vækning. Hjemmeplejen griner kærligt og påpeger at klokken jo næsten er 10 om formiddagen. "Nåh ja," svarer Betty, "men jeg er B, nej C-menneske!" Hjemmeplejeren skifter Bettys ble og hjælper hende med at blive vasket forneden. Hun henter et vandfad, så Betty selv kan vaske sig foroven, men Betty afslår: "Jeg har brug for kaffe. Kaffe og smøger." Hun roder på det overfyldte sengebord efter cigaretpakken og tænder smøgen, mens hun hoster dybt og rallende. Hjemmeplejeren kommer med en termokande med varmt kaffevand og en skål med havregryn. Derefter finder hun æsken med medicin, der er præpakket af apoteket og river den lille pose med morgenpillerne af. Hun tjekker, at datoen og antallet stemmer og hælder pillerne i et lille glas, som hun sætter foran Betty. "Åh, jeg hader at sluge piller" sukker Betty og går i gang med, en efter en, at fiske pillerne op af glasset og synker dem højlydt, en ad gangen, med en tår kaffe. Otte piller af forskellige størrelse tager noget tid, og hjælperen venter tålmodigt på, at alle pillerne bliver slugt. "Ja, jeg skal jo se hende sluge dem" siger hjemmehjælperen henvendt til mig. "Hvorfor?" spørger jeg. "Jo, det er en del af ydelsen her. De skal ses indtaget, hedder det". Betty vrisser lidt men forholder sig ellers tavs. Efter morgenmaden skal Betty på toilettet. Det foregår ved, at hjemmeplejen guider hende over i kørestolen ved hjælp af et glidebræt og her fra over i bækkenstolen, der er placeret i rummet ved siden af stuen. Bettys badeværelse er for lille til, at hun kan komme derud. Imens Betty er væk, skifter hjemmeplejen sengetøjet. Hun finder en pille i et hul i madrassen. Uden at sige noget viser hun mig pillen og ruller med øjnene. Efter hjemmehjælperen er gået, spørger jeg Betty, hvorfor hun får medicin. "Ja, det ved jeg sgu ikke. Det er jo lægen, når han kommer. Jeg siger bare ja!" griner hun og hoster den rallende hoste. "Og så bliver de så glade, når man tager de piller. Jeg kan ikke svare dig på, om jeg har det anderledes." Betty tænder endnu en smøg og hoster igen. "Ja, jeg kan jo lige så godt nyde det sidste, jeg har af mit liv, ik", griner hun i reference til smøgen. Tonen bliver mere alvorlig "Jeg gør sgu som det passer mig" Hun inhalerer, hoster og fortsætter sætningen "... eller hvad jeg nu kan, $i k !$ ". Betty læner sig tilbage i sengen med smøgen i munden, mens hun zapper efter noget at se på fjernsynet.

Farmakologikken har et indlejret ideal om god og korrekt medicinanvendelse indfanget af termen god compliance (at medicinen bliver taget som foreskrevet af lægen). I denne logik er det ufravigeligt godt, hvis borgere som Betty tager deres medicin (og helst uden for meget brok). Men Betty er, som de fleste andre ældre jeg 
har mødt, ikke særlig begejstret for at tage medicin. Det er ubehageligt at skulle sluge de mange piller men måske lige så ubehageligt at skulle holdes øje med. De ældre, der har tildelt ydelsen "skal ses indtaget", er dem, hvor plejepersonalet og/ eller de pårørende ikke er sikre på, om den ældre selv er i stand til at tage medicinen på forsvarlig vis. Om der er tale om glemsel eller modstand, siger ydelsen ikke noget om, men blot at ydelsen findes, er med til at fremme et fokus på compliance i hjemmeplejens arbejde med medicin. Situationen, hvor hjemmeplejeren skulle holde øje med, at Betty slugte pillerne, føltes akavet og ubehageligt for mig som observatør, og mit umiddelbare indtryk var, at Betty havde samme oplevelse. Koning og Ooi (2013) referer til akavede møder som etnografiske nedslagspunkter med stor analytisk potentiale: "Acknowledgement and analysing such awkwardness shows how macroscopic social institutions, in terms of values, beliefs, behaviour and practice, are enacted, practiced and negotiated in "reality" (30). I eksemplet med Betty bliver det således tydeligt, at medicinen ikke kun udgør et praktisk, men også et moralsk anliggende, der har betydning for forholdet mellem Betty og hjemmeplejen. Bettys oplevelser med medicin synes ikke at passe ind i farmakologikkens rationale for korrekt og sikker medicinanvendelse. Det er ikke for hendes skyld, hun tager piller, men for "alle de andres", og hun er ikke engang sikker på, at medicinen gør en forskel for hende. I praksis får sådanne ytringer lov at leve uberørt videre, da farmakologikken ikke foreskriver et behov for at undersøge borgerens ønsker til medicin. Tværtimod er logikken selvforstærkende, da hjemmeplejen ofte erfarer, at de ældre ikke er i stand til at tage medicinen på forsvarlig vis, hvilket kun bekræfter dem i, at det er deres ansvar at sikre god compliance. Det er det, der sker, da hjemmehjælperen finder en pille i Bettys madras. Rullet med øjnene kunne lige så vel have været et "se selv - hun gør det ikke ordentligt!" Der er ingen tvivl om, at plejeren ser det som en del af hendes ansvar at sørge for at Betty får sin medicin, og at det at sikre god compliance anses af hende som at yde et godt omsorgsarbejde. Men for Betty synes oplevelsen nærmere at være et tegn på magtanvendelse. Betty forsøger at kompensere ved selv at yde en smule modstand i det handlerum, hun har tilbage - hun ryger, selvom hun sikkert har fået at vide mange gange, at hun ikke må - særligt når hjemmeplejen er i hjemmet. Og hun gemmer en pille i madrassen i ny og næ, når hjemmehjælperen kigger væk. Disse små handlinger anses i farmakologikken som afvigelser men kunne med rette også anses som en måde for den enkelte at forsøge at forbedre sin hverdag på. 


\section{Hvad er god lægemiddelomsorg for ældre i sårbare situationer?}

Forbruget af lægemidler er højt i Danmark men også ulige fordelt. Særligt de ældre har et stort forbrug af receptpligtig medicin (Pedersen et al., 2020), og medicinhåndteringen fylder tilsvarende meget $\mathrm{i}$ hjemmeplejens arbejde (Kjellberg, 2018). I denne artikel har jeg zoomet ind på dette lægemiddelarbejde og på, hvordan dette arbejde er styret af en særlig måde at anskue og praktisere medicin på, som jeg kalder farmakologik. Gennem tre empiriske eksempler har jeg vist 1) at farmakologikken flytter fokus væk fra medicinens sociale effekter 2) at farmakologikken gør lægemiddelarbejdet til et instrumentelt og reduktionistisk pille-pilleri og 3) at farmakologikken fremmer et fokus på god compliance, der skaber akavethed $\mathrm{i}$ mødet med den ældre, der udviser modstand. Når farmakologikken møder hverdagslivet opstår spændinger, der både kan forårsage, at omsorgsarbejdet finder et rum at virke i, men også at specifikke normer for god lægemiddelhåndtering og anvendelse bliver styrende for hjemmeplejens arbejde med medicin. Farmakologikken fanger så at sige både hjemmeplejen og borgerne i nogle særlige forestillinger om, hvad godt lægemiddelarbejde er.

Med diskussionen her ønsker jeg hypotetisk at afprøve, om man gennem eksemplerne kan tænke en anden form for logik som den styrende - nemlig lægemiddelomsorgens logik. Så hvad ville der ske, hvis vi forsøgsvis applicerede lægemiddelomsorgens logik på mødet med demente Olav? Måske man i stedet for primært at tænke: mon medicinen kan få Olav til at falde til ro, havde tænkt: hvad mon skaber denne uro i Olav, og hvordan kan medicinen blive medaktør i forsøget på at gøre hverdagen i hjemmet nemmere. Med lægemiddelomsorgens logik er målet ikke at tage eller undgå medicin men at være opmærksom på, hvad medicinen gør - hvilken rolle den indtager og hvad den erstatter. Uden at vide det kunne Olav meget vel blive en af de mange der får antidepressiva med sig i graven, fordi medicinen umiddelbart synes at virke i praksis. Men så længe farmakologikken ikke anerkender effekter, der rækker udover de biomedicinsk dokumenterede, kan medicinens sociale liv ikke retfærdiggøres og hermed ikke få værdi i den videre behandling af Olav. I lægemiddelomsorgens logik ville man sætte tid af til at prøve noget andet. Måske man kunne sørge for, at færre personer kom i hjemmet, og at relationen til disse få blev stærkere. Måske man så efterfølgende kunne prøve, om Olav faktisk kunne undvære medicinen. I lægemiddelomsorgens logik ville man rette et kontinuerligt fokus på forandringer i den enkeltes liv og løbende sikre, at medicinen fortsat er berettiget. 
Hos de multisyge kommer medicinen særligt til udtryk gennem fænomenet polyfarmaci eller samtidig behandling med flere præparater dagligt. Gennem eksemplet med Carl viste jeg, hvordan polyfarmaci i praksis omsættes til pille-pilleri, forstået som det krævende arbejde det er at sikre, at borgerne får den korrekte behandling. En helt specifik måde, hvorpå farmakologikken rammesætter dette arbejde, er igennem et udtalt fokus på dokumentation. Farmakologikken fremmer således juridiske og instrumentelle aspekter af lægemiddelarbejdet, der gør, at det praktiske arbejde med medicinen tager al hjemmeplejens tid. I lægemiddelomsorgens logik er tid sammen med lægemiddelbrugeren lige så vigtig som tid sammen med medicinen. Målet er ikke at gå på kompromis med sikkerheden, ej heller at negligere vigtigheden af at få doseret medicinen korrekt. Det kræver en omstrukturering af lægemiddelarbejdet, der sikrer, at hjemmesygeplejen fx ikke bruger unødig tid på at komme forgæves i borgerens hjem, fordi medicinen ikke er fysisk til stede til at blive doseret. Vi har i dag desuden masser af teknologiske muligheder for at få hjælp til dosering af komplekse medicinlister (heriblandt dosispak eller endda robotter i hjemmet, selvom jeg er helt bevidst om, at en implementering af den type teknologi ej heller er problemfri). Jeg tror dog på, det godt kan lykkes at frigive noget af sygeplejens tid gennem en klogere fordeling af arbejdsopgaver. I lægemiddelomsorgens logik bruges det ekstra tid dog ikke på andre sygeplejerelaterede opgaver, men på at skabe lægemiddelomsorg - det er, gennem løbende observation og dialog med den ældre at sikre at medicinen er gavnlig og meningsfuld i hverdagen, også når hverdagen forandrer sig pga. nye symptomer, indlæggelser eller andre uforudsigeligheder.

Endelig er farmakologikken også med til at fremme en særlig moralsk fortælling om medicins rolle i hverdagslivet. Fx er det godt, hvis borgeren udviser god compliance og tager sin medicin, når hjemmeplejen har forberedt den og stillet den frem (og helst på de ordinerede tidspunkter fx kl. 8, 12 og 18). Men det er ikke godt, hvis borgeren fravælger medicinen eller måske ligefrem gemmer den i madrassen. I feltarbejdet så jeg mange eksempler på sådanne "forkerte" praksisser, hvor medicinen ikke blev indtaget korrekt (noget medicin skal tages med mad, andet forskudt af måltider), eller hvor der blev sjusket med opbevaringen ( $f x$ hvis medicinen var spredt over hjemmet, eller hvis medicin var pillet ud af pakkerne men ikke placeret i doseringsæskerne). Farmakologikken fremmer altså en forståelse af korrekt lægemiddelhåndtering og anvendelse som noget meget statisk og fastlåst, hvilket kommer til udtryk på akavet vis i relationen til de ældre, der udviser modstand mod medicin. I lægemiddelomsorgens logik findes der i udgangspunktet ikke en rigtig eller forkert måde at tage medicin på (så længe 
medicinbrugeren selvfølgelig ikke er i fare!). Målet er derfor ikke udelukkende at følge mere eller mindre betydningsfulde behandlingsregimer, men derimod at sørge for at medicinen løbende er tilpasset den ældres hverdagsliv. Fokus flyttet fra kontrol til tilpasning. For Betty kunne man overveje, om medicinen overhovedet giver mening - eller om Betty ville have det lige så fint med at leve sin sidste tid uden de irriterende piller.

\section{Konklusion}

I denne artikel har jeg interesseret mig for, hvad lægemidler, særligt antidepressiva, gør i mødet mellem hjemmeplejen og ældre, sårbare borgere. Inspireret af Annemarie Mol (2008), har jeg beskrevet to måder at anskue og praktisere dette lægemiddelarbejde på - farmakologikken og lægemiddelomsorgens logik. Den første, farmakologikken, er styret af biomedicinens rationaler for god lægemiddelhåndtering. Jeg har gennem empiriske eksempler vist, at farmakologikken dominerer hjemmeplejens arbejde med medicin. Farmakologikken introducerer en række normer for, hvordan lægemiddelarbejdet skal foregå, hvor hjemmeplejen er autoriteten og den ældre en passiv medicinmodtager. Farmakologikker fremmer således nogle særlige måder at anskue og praktisere god medicinering på, som fx ikke inkluderer et blik for medicinens sociale egenskaber eller de ældres egne oplevelser og erfaringer med medicin. Med artiklen ønsker jeg at foreslå et alternativ til denne tilgang til lægemiddelarbejdet, nemlig lægemiddelomsorgen. I lægemiddelomsorgens logik er udgangspunktet de relationelle forbindelser mellem medicinen, den ældre og andre vigtige aktører i den specifikke omsorgskonstellation. I lægemiddelomsorgens logik er løsningen ikke nødvendigvis mindre medicin men en større opmærksomhed på medicinens effekter (både individuelle, sociale, moralske og teknologiske) i mødet mellem de sundhedsprofesionelle og ældre, og på hvordan disse effekter forandres, når omsorgskonstellationen ændrer sig. Jeg tror på, at hvis vi bliver bedre til at få øje på og italesætte de komplekse, relationelle konstellationer, som lægemidler er en del af, kan vi også i højere grad sikre, at lægemidlerne faktisk bidrager med omsorg i hverdagen hos dem, der håndterer og bruger dem. 


\section{Taksigelser}

Tak til Velux Fonden for at muliggøre dette studie. Stor tak til Mette Bech Risør og Julie Høgsgaard Andersen for kommentarer til tidligere versioner af denne artikel, og til de to anonyme bedømmere. Særlig bedømmer Bs grundlige gennemlæsning og forslag til bedre kobling af teori og empiri, styrkede artiklens bidrag væsentligt. Tak til informanterne - ældre borgere, hjemmepleje og læger - for jeres tid og lyst til at dele hverdagen med mig.

\section{Noter}

${ }^{1}$ Teoretisk skal min brug af termen omsorg forstås ud fra en bred, eklektisk tilgang inspireret af Buch (2015). Buch foreslår, at omsorg skal forstås flertydigt, hvilket muliggør studier, der kan binde bro mellem makroanalyser af omsorg ud fra et politik/økonomisk perspektiv med mikroanalyser af, hvad omsorg er og gør mellem specifikke personer. Som Buch skriver: "Both care practices and political economies of care play crucial role in the constitution of personhood. Simultaneous attention to both thus clarifies the stakes of diverse forms of care." (ibid.:281). Mødet mellem hjemmepleje og borger er således stærkt forbundet med den danske velfærdsstats model for ældreomsorg, ligesom lægemidlernes virke i hverdagslivet og klinisk praksis er stærkt forbundet med både den statslige og private regulering af medicin og med lægemiddelindustriens påvirkning af vores opfattelser af sundhed og sygdom (Dumit, 2012; Greene, 2007).

2 Ved antidepressiva forstås lægemidler i ATC-gruppen N06A, bortset fra bupropion (N06AX12), der bruges til rygeafvænning, og duloxetin (N06AX21) i styrken 20mg og $40 \mathrm{mg}$, der bruges til stressinkonsistens (jf. Sundhedsdatastyrelsen, 2017)

${ }^{3}$ I artiklen anvender jeg til tider betegnelsen "borger" for de ældre, der var med i projektet. Borger resonerer på mange måder med en form for "citizenship" eller statsborgerskab, hvilket kendetegner personer, der er underlagt en form for statslig styring men også har rettigheder og ressourcer stillet til rådighed gennem staten. I denne artikel anvendes begrebet dog primært fordi, det er den term, personalet i hjemmeplejen bruger. I kontekst hertil kan nævnes, at de praktiserende læger primært anvender termen "patienter" om de ældre, der har en tilknytning til deres klinik. Da mødet med deltagerne primært foregik i hjemmet og i personernes private sfære, hvor patient-terminologien synes fremmed, anvendes ikke dette begreb. I det hele taget forsøger jeg så vidt muligt at tale om "deltagerne" eller "de ældre" i projektet for at undgå indlejrede magtdiskurser rettet mod både staten og det medicinske domæne. 


\section{Referencer}

Abraham, J. (2010). Pharmaceuticalization of society in context: theoretical, empirical and health dimensions. Sociology 44, 603-622. https://doi.org/10.1177/0038038510369368

Bell, S.E. \& Figert, A.E. (2012). Medicalization and pharmaceuticalization at the intersections: Looking backward, sideways and forward. Soc. Sci. Med. 75, 775-783. https://doi. org/10.1016/j.socscimed.2012.04.002

Buch, E.D. (2015). Anthropology of Aging and Care. Annu. Rev. Anthropol. 44, 277-293. https://doi.org/10.1146/annurev-anthro-102214-014254

Christensen, L.D.; Reilev, M.; Juul-Larsen, H.G.; Jørgensen, L.M.; Kaae, S.; Andersen, O.; Pottegård, A. \& Petersen, J. (2019). Use of prescription drugs in the older adult population-a nationwide pharmacoepidemiological study. Eur. J. Clin. Pharmacol. 75, 11251133. https://doi.org/10.1007/s00228-019-02669-2

Clarke, A. E.; Shim, J. K.; Mamo, L.; Fosket, J. R. \& Jennifer, R. (2003). Biomedicalization: Technoscientific Transformations of Health, Illness, and U.S. Biomedicine. Am. Sociol. Rev. 68, 161-194. https://doi.org/10.2307/1519765

Collin, J. (2016). On social plasticity: the transformative power of pharmaceuticals on health, nature and identity. Sociol. Health Illn. 38, 73-89. https://doi.org/10.1111/14679566.12342

Dumit, J. (2012). Drugs for Life: How Pharmaceutical Companies Define Our Health. London: Duke University Press.

Felding, S.A. \& Schwennesen, N. (2019). Når omsorgen udliciteres. En analyse af den konfliktfyldte omsorgstrojka mellem mennesker med demens, pårørende og plejepersonale på et plejehjem i Danmark. Tidsskr. Forsk. i Sygd. og Samf. 30, 123-149. https://doi. org/10.7146/tfss.v15i30.114771

Gabe, J., Williams, S., Martin, P. \& Coveney, C. (2015). Pharmaceuticals and society: power, promises and prospects. Soc. Sci. Med. 131, 193-8. https://doi.org/10.1016/j.socscimed.2015.02.031

Greene, J.A. (2007). Prescribing by Numbers: Drugs and the Definition of Disease. Baltimore: The Johns Hopkins University Press.

Grøn, L. \& Andersen, C. R. (2014). Sårbarhed og handlekraft $i$ alderdommen: Et etnografisk feltarbejde blandt fagpersoner og ældre $i$ Horsens og omegn. Udgivet af KORA (Det Nationale Institut for Kommuners og Regioners Analyse og Forskning). Tilgængelig fra: https:// www.vive.dk/media/pure/9035/2042778

Hardon, A. \& Sanabria, E. (2017). Fluid Drugs: Revisiting the Anthropology of Pharmaceuticals. Annu. Rev. Anthropol. 46, 117-132. https://doi.org/10.1146/annurev-anthro-102116-041539

Hasse, C. \& Wallace, J. (2014). Omsorgsteknologier. In Hunicke, L. \& Olesen, F. Teknologi i Sundhedspraksis, 83-100. Munksgaard, København.

Hickie, I. (2011). Antidepressants in elderly people. BMJ.343, d4660. https://doi:10.1136/bmj. d 4660

Jöhncke, S.; Nordahl Svendsen, M. \& Whyte, S. R. (2004). Løsningsmodeller. Sociale teknologier som antropologisk arbejdsfelt. In Hastrup, K. (Ed.), Viden Om Verden, 385-408. København: Hans Reitzels Forlag. 
Kjellberg, J. (2018). Bruger vi sygeplejerskernes tid bedst muligt i kommunerne? VIVE Det Nationale Forsknings- og Analysecenter for Velfærd. Tilgængelig fra: https://www.vive. dk/da/udgivelser/bruger-vi-sygeplejerskernes-tid-bedst-muligt-i-kommunerne-11185/

Koning, J. \& Ooi, C.-S. (2013). Awkward encounters and ethnography. Qual. Res. Organ. Manag. 8, 16-32. https://doi.org/DOI:10.1108/17465641311327496

Lau, S.R. (2020). “Som at spille Kalaha”: Polyfarmaci i den kommunale hjemmepleje. Tidsskr. Gerontol. 1, 8-13.

Lundby, C.; Jensen, J.; Larsen, S. P.; Hoffmann, H.; Pottegård, A. \& Reilev, M. (2020). Use of medication among nursing home residents: a Danish drug utilisation study. Age Ageing 00, 1-7. https://doi.org/doi: 10.1093/ageing/afaa029

Midlöv, P.; Andersson, M.; Östgren, C. J. \& Mölstad, S. (2014). Depression and use of antidepressants in Swedish nursing homes: a 12-month follow-up study. Int. Psychogeriatrics 26, 669-675. https://doi.org/10.1017/S1041610213002354

Mol, A. (2008). The Logic of Care: Health and the Problem of Patient Choice. London, New York: Routledge.

Mol, A. (2002). The body multiple: Ontology in medical practice. Durham and London: Duke University Press. https://doi.org/10.1017/S174585520722558X

Mol, A.; Moser, I. \& Pols, J. (2010). Care in Practice. On Tinkering in Clinics, Homes and Farms. Bielefield: Transcript-Verlag.

Pedersen, J. K.; Jensen, T. M.; BochWaldorff, F.; Søndergaard, J. \& Christensen, K. (2020). Use of prescription medication in the last years of life: a population-based comparison of two oldest old Danish birth cohorts born 10 years apart. Age Ageing 49, 1105-1109. https://doi.org/https://doi.org/10.1093/ageing/afaa064

Rosenberg, C. E. (2006). Contested Boundaries: psychiatry, disease, and diagnosis. Perspect. Biol. Med. 49, 407-424. https://doi.org/10.1353/pbm.2006.0046

Rosholm, J.-U.; Nybo, H.; Andersen Ranberg, K.; Himmelstrup, B.; Skjelbo, E.; Christensen, K. \& Gram, L. F. (2002). Hyponatraemia in very old nonhospitalised people: association with drug use. Drugs Aging 19, 685-93.

Søndergaard, B.; Herborg, H.; Knudsen, P. \& Rossing, C. (2006). Evidensrapport 7 Kortlægning af lægemiddelrelaterede problemer. Version 2.1. Pharmakon. https://www.pharmakon.dk/media/1398/rapport-7-21-2006_web_ny-ref_samlet.pdf

Styrelsen for Patientsikkerhed (2019). Korrekt håndtering af medicin: Et værktøj for plejecentre, hjemmepleje, hjemmesygepleje, bosteder mv. Ansvar, sikkerhed og opgaver. 2. udgave. https://stps.dk/da/ansvar-og-retningslinjer/vejledning/haandtering-af-medicin/ / media/0E30EDB960FA47DBA41FDA577A0AB979.ashx

Sundhedsdatastyrelsen (2020). Lægemiddelstatistik. www.medstat.dk (accessed 6.3.20).

Sundhedsdatastyrelsen (2017). Laveste antal brugere af antidepressiv medicin de seneste 10 år. Indblik. https://sundhedsdatastyrelsen.dk/da/tal-og-analyser/analyser-og-rapporter/ laegemidler/emnespecifikke-analyser/analyser-om--antidepressiva

Whyte, S. R.; Geest, S. van der \& Hardon, A. (2002). Social Lives of Medicines. Cambridge: Cambridge University Press.

Wiese, B. (2011). Geriatric depression: The use of antidepressants in the elderly. BC Med. J. 53, 341-347.

Wilkinson, P.; Ruane, C. \& Tempest, K. (2018). Depression in older adults. BMJ 363, k4922. https://doi.org/10.1136/bmj.k4922 
Will, C. M. (2017). On difference and doubt as tools for critical engagement with public health. Crit. Public Health 27, 293-302. https://doi.org/10.1080/09581596.2016.1239815 